Some British Moths

By Norman Riley. (King Penguin Book.) Pp. $\mathrm{ii}+30+16$ coloured plates. (Harmondsworth and New York: Penguin Books, Ltd., 1944.) $2 s$.

A LL moths are not clothes moths, nor do all caterpillars eat cabbages, as many laymen still believe. There is much ignorance to dispel, and at the same time a growing appetite for knowledge of wild life to satisfy. This attractively written and produced book should gain both these ends, opening up new fields of pleasure for the man whose garden and now lighted windows attract so many moths, or who takes his leisure in the countryside.

Writing simply but vividly, the author gives an account of the moth's life-history-the various tricks that protect it from its enemies, the marvels of its eyes and organs of touch and smell, how it finds its mate, etc.- that makes fascinating reading. Caterpillars, not merely objects of interest, are shown as living animals with their own problems of concealment and protection, feeding and final transformation.

The forty-six moths illustrated, most of which ean easily be found or reared, are necessarily a small selection, but they represent most of the 'macro' families, and the family likenesses are usefully pointed out. Notes on when and where the moths occur and how they live are given. The coloured plates are from drawings by the eighteenth century naturalist Moses Harris, some of which are published for the first time. Their freshness and richness of colour and the life-like attitudes, with larva, pupa and food plant also depicted, make them attractive illustrations. One or two of the smaller figures are perhaps rather blurred for identification purposes.

\section{The Distribution of the Birds of California}

By Joseph Grinnell and Alden H. Miller. (Pacific Coast Avifauna, No. 27.) Pp. 608. (Berkeley, Calif. : Cooper Ornithological Club, 1944.) n.p.

THIS work was commenced by the late Joseph Grinnell in 1934, and before he died in 1939 he had completed about half the species. In $1940 \mathrm{Mr}$. Alden Miller undertook to finish the volume and, in addition, to revise the typescript already prepared.

Under each species there is a list of synonyms which apply to Californian birds. The information is arranged under three headings: status, geographical range and habitat. The first, in addition to stating whether the bird is common or local, has some remarks on migration. The paragraph dealing with the range of the species gives all the records of distribution over the whole area and any which refer to nesting or occurronces on migration. In every case the authority or reference is added to each record. The final paragraph describes the type of country occupied by the birds during the broeding and nonbreeding season. At the end of the book there is a supplementary list of introduced birds and species of uncertain occurrences.

Hence this is solely a detailed record of the distribution of Californian birds, which must have taken an immense amount of labour to compile.

There is no summary or deductions to finish off the work, but at the end of the introduction Mr. Miller states that it is hoped to publish later information dealing with various aspects of Californian bird-life, such as the differentiation centres for races, intrusions of faunas from adjoining continental areas, and other problems. This will be a very valuable contribution, and we shall look forward to Mr. Miller's additional volume. There is one coloured plate and a number of useful maps showing the distribution of various races.

\section{Garden Birds}

By Phyllis Barclay-Smith. (King Penguin Book.) Pp. ii $+30+20$ coloured plates. (Harmondsworth and New York: Penguin Books, Ltd., 1945.) $2 s$.

NANY persons who are not skilled ornithologists 1 take a considerable interest in birds, particularly those that visit their gardens, and they feel the need for a concise, well-written, well-illustrated, inexpensive book to help them recognize their garden inhabitants and visitors. This want has been supplied by Miss Barclay-Smith. She writes of the different types of gardens and the birds likely to be seen in them, of what can be done in the way of planting special trees and bushes to encourage birds, of the plants they like, about deterrent measures against cats, the provision of nesting boxes and how to make them, also the provision of nesting material, and lastly the necessity to supply food and water. Feeders are discussed and the food to be supplied, reference being made to the widespread idea that coco-nut may prove fatal to tits. She says, "it is open to doubt. It is, however, a good thing to spread the nut with lard occasionally to prevent it becoming too hard." The reviewer in pre-war days when coco-nuts were easily obtained always had two or three hung up for the benefit of the tits and never knew a bird any the worse. Miss Barclay-Smith goes on to give individual descriptions of some score of regular garden birds in Britain, her accounts being illustrated by twenty colour reproductions of plates from Gould's "Birds of Great Britain", which are ever vivid and fresh.

F. P.

\section{Faiths of Many Lands}

By E. Royston Pike. Pp. viiit-103. (London : Watts and Co., Ltd., 1945.) 8s. 6d. net.

$T$ HE world contains many great and interesting religions. To most of us in Great Britain the greater number are merely names. In this unusual little book they become realities, and we read not only of the religions and their founders, but also of the millions who practise these religions, and what effect they have on the lives of the believers. The style is vivid and direct, and certainly arouses interest in the subject.

It is meant for children, but I think it is more suitable for adolescents, or for those who know very little about the subject, and want a simple, interesting introduction to it. It will give many an inclination to go further and read yet more about the Buddhists, the Mohammedans, the Hindus, the Parsees and so forth.

Enid Blyton.

\section{Recent Advances in Endocrinology}

By Prof. A. T. Cameron. Fifth edition. Pp. vii +415 . (London: J. and A. Churchill, Ltd., 1945.) $18 s$.

7 HE fifth edition of this book is well up to date. More clinical detail is given here than in previous editions, and this makes the whole more coherent and readable. Among the mass of added material may be found descriptions of the use of 'tagged' atoms in the investigation of thyroid metabolism and of the use of thiouracyl and thiourea in hyperthyroidism. There are some new illustrations and a com. prehensive bibliography. 